\title{
СоцИологИЯ
}

DOI: 10.17805/trudy.2016.5.1

\section{КАФЕДРА СОЦИОЛОГИИ МОСКОВСКОГО ГУМАНИТАРНОГО УНИВЕРСИТЕТА}

\author{
А. И. Ковалева, В. А. Луков \\ (Московский гуманитарный университет)
}

\begin{abstract}
Аннотация: В статье анализируется вклад кафедры социологии в развитие научной школы социологии молодежи Московского гуманитарного университета, рассматриваются основные теоретические концепции, разработанные преподавателями кафедры, их участие в исследовательских проектах, в том числе поддержанных российскими научными фондами (РГНФ, РФФИ, Роснаука) и международными организациями (ЮНЕСКО, ЮНИСЕФ).

Ключевые слова: Московский гуманитарный университет; кафедра социологии МосГУ; научная школа социологии молодежи; социология молодежи; концепция социализационной нормы; концепция социализационной траектории; тезаурусный подход; биосоциология молодежи
\end{abstract}

\section{THE DEPARTMENT OF SOCIOLOGY AT MOSCOW UNIVERSITY FOR THE HUMANITIES}

\author{
A.I. Kovaleva, Val.A. Lukov \\ (Moscow University for the Humanities)
}

\begin{abstract}
The article examines the contribution made by the faculty at the Department of Sociology, Moscow University for the Humanities, to the university's academic school of sociology of youth. The authors look at the major theoretical concepts introduced by researchers affiliated with the department, their participation in a number of research projects, including those supported by Russian foundations and institutions (RFH, RFBR, Rosnauka) and intergovernmental bodies (UNESCO, UNICEF).

Keywords: Moscow University for the Humanities; Department of Sociology, MosUH; research school of sociology of youth; sociology of youth; socialization norm; socialization trajectory; thesaurus approach; biosociology of youth
\end{abstract}

Кафедра социологии Московского гуманитарного университета функционирует с 1969 г., т. е. со времен Высшей комсомольской школы при ЦК ВЛКСМ. Ее наименование несколько раз уточнялось с учетом корректировки задач кафедры как учебного и научного подразделения (кафедра конкретных социологических исследований, кафедра социологии и социальной психологии, кафедра социологии и социальной работы). 
Все эти годы кафедра занималась изучением проблем молодежи, объединяя свои усилия сначала с Научно-исследовательским центром ВКШ при ЦК ВЛКСМ, в настоящее время - с Институтом фундаментальных и прикладных исследований МосГУ. Научная школа социологии молодежи Московского гуманитарного университета возникла как итог теоретического осмысления материалов обширных и систематических исследований проблем молодежи. Ее основу составляют теоретические концепции молодежи, молодежной политики, молодежного движения, социализации И.М.Ильинского, А. И. Ковалевой, Вал. А. Лукова. Приоритеты научной школы социологии молодежи МосГУ подтверждены публикациями крупных научных монографий, статей как в России, так и в более чем 20 зарубежных стран, а также статьями о научной школе, ее представителях и их трудах в биобиблиографическом словаре «Социологи России: История социологии в лицах» (М., 2014), энциклопедических изданиях - «Социологической энциклопедии» (М., 2003), энциклопедическом словаре «Социология молодежи» (М., 2008), выпущенными Российской академией науки др.

В теоретико-методологическом плане на кафедре выдвинуто ряд концепций, на которых строится исследовательская практика и подготовка новых поколений исследователей-социологов в Московском гуманитарном университете. Основные положения этих концепций могут быть вкратце изложены следующим образом.

Концепция социализационной нормы.Разработана в 1997 г.А.И. Ковалевой и применена ею в анализе особенностей и результативности социализации молодежи. Социализационная норма определяется, во-первых, как результат успешной социализации, позволяющей индивидам воспроизводить социальные связи, общественные отношения и культурные ценности данного общества и обеспечивать их дальнейшее развитие; вовторых, как многомерный эталон социализированности человека с учетом его возрастных и индивидуально-психологических характеристик; в-третьих, как устоявшуюся в обществе совокупность правил передачи социальных норм и культурных ценностей от поколения к поколению (Ковалева, 1997: 7-8). Социализационная норма выступает мерой социализированности индивида в соответствии с характеристиками социальности данного общества. Хотя социализационная норма тесно связана с нормой социальной, она не должна сводиться к последней. «Суть различия состоит в назначении той и другой нормы: для социальной нормы таким назначением является регуляция поведения индивида и группы, для социализационной - регуляция вместе с освоением нормы (адаптация к ней и ее интериоризация индивидом, как основного свойства, как differentia specifica). Цель регуляции - передача социальной нормы. Субъектно-объектная сторона регулирования определяется отношениями «передающий - усваивающий» («учитель - ученик»)» (там же: 18). 
Выделение социализационной нормы продуктивно для исследования детей и молодежи, поскольку именно она (а не общая социальная норма) выстраивает каркас социального статуса человека в период детства и юности. Вероятно, социализационная норма действует и на следующих возрастных этапах, но ее значение там ограничено и ориентирующее значение и для личности, и для общества имеет преимущественно социальная норма. Столь же значима концепция социализационной нормы для более точной трактовки социального статуса молодых людей с ограниченными возможностями (имеющими отклонения в физическом и умственном развитии, неслышащими и др.), что показали исследования, проведенные под руководством и с участием А. И. Ковалевой (Ковалева, Реут, 2001; Жулковска, Ковалева, Луков, 2003). В результате, например, удалось выявить ранее не осознававшиеся противоречия в социальном положении молодых людей с инвалидностью и в адресованных им образовательных программах.

Концепция социализационной траектории. Развита А. И. Ковалевой в работах 1999 г. и последующих лет. Социализационная траектория, по Ковалевой, представляет собой специфическую для конкретного человека совокупность характеристик направленности, хода и результативности процесса его социализации. Социализационная траектория в таком случае выступает интегральным показателем характера социализации. Траекторная модель социализации индивида показывается А. И. Ковалевой в нескольких срезах: (1) влияние внешней среды, (2) субъектность и (3) диспозиция личности в процессе социализации. «Алгоритм построения социализационной траектории основывается не на статических состояниях, а на динамике процесса социализации с учетом пройденного индивидом этапа жизненного пути, причем основные характеристики измеряются во временном континууме» (Ковалева, Луков, 1999).

Работы А. И. Ковалевой и ее учеников позволили внести существенный вклад в развитие теории социализации в ее собственно социологическом аспекте. Это нашло отражение в ряде публикаций последнего времени (Ковалева, 2011, 2006, 2012; Ковалева, Луков, 2012). В 2012 г. А.И.Ковалева вместе с В. В. Богдановой, подготовившей под ее научным руководством и успешно защитившей кандидатскую диссертацию, представила концепцию социализационной траектории в монографии «Траектория социализации» (Ковалева, Богданова, 2012).

Тезаурусный подход к социальным и культурным явлениям. Как общеметодологическая концепция применительно к гуманитарным наукам разработана в 1992-2014 гг. Вал. А. Луковым и Вл. А. Луковым (Луков Вал, Луков Вл., 2004, 2008, 2013, 2014 и др.) и применена Вал. А. Луковым при обосновании оригинальных теоретических концепций молодежи, социализации, социального проектирования. Эти идеи были применены как 
теоретико-методологическое основание в работах докторантов и аспирантов МосГУ Д. Л. Аграната, М. В. Вдовиной, И. Г. Биченко, В.В. Воробьева, А.В.Доскальчука, М.Я. Курганской,А. В.Лукова, С. В.Лукова,Ю.Е.Надточия, А. Г. Русановой, А. А. Ситникова, Д. А. Тихомирова, Е.А.Туринцевой и др.

Наиболее полное изложение тезаурусной концепции молодежи содержится в монографии Вал. А. Лукова «Теории молодежи: Междисциплинарный подход» (Луков, 2012). Некоторые новые аспекты концепции нашли отражение в монографии Вал. А. Лукова, написанной в соавторстве с Э. К. Погорским (Луков, Погорский, 2014).

Молодежь в рамках тезаурусной концепции трактуется как социальная группа, которую составляют (1) люди, осваивающие и присваивающие социальную субъектность, имеющие социальный статус молодых и являющиеся по самоидентификации молодыми, а также (2) распространенные в этой социальной группе тезаурусы и (3) выражающий и отражающий их символический и предметный мир. Тезаурусная концепция молодежи позволяет прояснить пути развития социальной субъектности молодежи и обнаружить ее противоречивые черты как в опредмеченной деятельности, так и в фактах самосознания, выполняющих важную регулятивную функцию.

Развитие тезаурусной концепции молодежи повлекло за собой разработку целого ряда фундаментальных категорий гуманитарных наук. Такова, в частности, категория социализации, в отношении которой выстроена следующая теоретическая гипотеза: (1) индивидуальные тезаурусы строятся в рамках социализационного процесса из элементов тезаурусных конструкций; (2) в обществе сосуществуют несколько тезаурусных конструкций с разной степенью актуальности (т. е. степенью распространенности, нормативности, формализации); соответственно, и на индивидуальном уровне возможно сосуществование нескольких тезаурусов и выстраивание тезауруса с подвижной иерархией элементов; (3) актуальность, актуализация и утеря актуальности тех или иных тезаурусных конструкций детерминированы объективными социальными процессами и субъективным определением ситуации (на различных уровнях социальной организации); (4) социализационные практики обеспечивают передачу и актуальных, и неактуальных тезаурусных конструкций, из которых строятся тезаурусы. Тезаурусный подход к социализации позволяет преодолеть некоторые противоречия социализационных теорий, он исходит из материалистического представления о социализации как процессе, имеющем своим основанием сложившиеся в обществе типы образа жизни. В то же время социализация в каждый данный исторический момент не является зависимой только от наличных условий бытия, от присущих данной эпохе образцов поведения и мышления и т. д. Кроме синхронии, 
есть еще и диахрония тезаурусных конструкций, и те или иные структуры могут переноситься сквозь века не непосредственно через каналы преемственности и смены поколений, но через сохранение, ретрансляцию и возрождение социокультурных кодов в их материализованной форме (тексты).

В области социального проектирования тезаурусный подход применен для обоснования субъектно-ориентированной концепции, согласно которой «социальное проектирование - это конструирование индивидом, группой или организацией действия, направленного на достижение социально значимой цели и локализованного по месту, времени и ресурсам» (Луков, 2010).

Этот аспект теоретических концепций, ориентированных на тезаурусный подход как на методологию исследования, оказался продуктивен для анализа и проектирования государственной молодежной политики. Это, в частности, было подтверждено реализацией на базе Московского гуманитарного университета научного проекта, поддержанного РГНФ и осуществленного группой молодых ученых университета под руководством Вал. А. Лукова. Этот проект предусматривал анализ мер в сфере государственной молодежной политики, направленных на раскрытие инновационного потенциала молодежи (Луков В., Луков С., Погорский, 2012; Государственная молодежная политика ..., 2013).

Биосоциология молодежи. В начале 2010-х гг., основываясь на гуманитарной концепции молодежи И. М. Ильинского, концепциях социализационной нормы и социализационной траектории А. И. Ковалевой и развивая свои теоретические концепции молодежи, молодежного движения, социализации, социального и культурного проектирования, Вал. А. Луков выдвинул концепцию биосоциологии молодежи. Ее базовые положения опубликованы в ряде статей (Луков, 2011ab и др.), а также в монографии «Биосоциология молодежи: теоретико-методологические основания» (Луков, 2013).

Под биосоциологией Вал. А. Луков понимает научную концепцию междисциплинарного характера, исходящую из неразрывной связи биологического и социального компонентов в жизни человека и человеческих сообществ (социальных общностей) и имеющую своим предметом те стороны социальной жизни, которые и на макроуровне, и на микроуровне человеческих взаимодействий непосредственно вытекают из биологической природы человека. Это в первую очередь вопросы гендера, возрастных различий, этнокультурной специфики, а также вопросы взаимодействия человека и человечества с искусственным миром, созданным ими и отчужденными от себя. Из этого, в частности, следует, что биосоциология - не альтернатива общесоциологическим теориям, она не содер- 
жит в себе парадигмального основания организации социологического знания. Ее место в современном гуманитарном знании определяется по той же модели, какая закрепилась в биоэтике.

На основе теоретико-методологической концепции биосоциологии могут быть выявлены и осмыслены возможные трансформации общества через накопление критической массы биологических и интеллектуальных (под воздействием факторов внешней среды обитания и вызванных искусственными средствами), а также социокультурных изменений в новых поколениях, что позволит также спрогнозировать с применением гуманитарной экспертизы изменения статуса-роли молодежи в обществе.

С середины 90-х гг. XX века кафедра социологии способствовала закреплению роли МосГУ как ведущей научной организации в таких областях, как теория социализации, социология молодежной политики, социология детства, социальное проектирование, социальная инноватика и др. Хотя социологическая тематика, разрабатываемая в МосГУ, с этого времени значительно расширилась, в основных исследованиях доминанта молодежной проблематики не только сохранилась, но и приобрела новые черты как в теоретико-методологическом, так и в эмпирическиприкладном аспектах. Немалую роль в этом сыграли опубликованные участниками научной школы в издательстве Московского гуманитарного университета монографии (Агранат и др., 2005; Луков, Агранат, 2005; Васильева, Кочнев, 2012; Селиверстова, Юмашева, 2009 и др.) и сборники научных трудов, а также статьи в созданном в 2004 г. научном журнале МосГУ «Знание. Понимание. Умение» (Перинская, 2005; Ромашова, 2013; Селиверстова, 2009, 2011; Усманов, 2012 и др.), который с 2008 г. входит в число изданий так называемого «списка ВАК», в том числе по социологическим наукам.

Существенно также и то, что в период с 1991 по 2012 гг. (в течение 22 лет) в университете функционировал диссертационный совет по социологическим наукам. Диссертационный совет по защите кандидатских диссертаций по социологическим наукам функционировал в вузе на основании приказа Высшей аттестационной комиссии при Совете министров СССР от 16 апреля 1991 г. № 1570-в, по защите докторских диссертаций - на основании приказа Высшей аттестационной комиссии России от 21 июля 1994 г. № 307-в. За это время были подготовлены и защищены 19 докторских и 145 кандидатских диссертаций по социологическим наукам, в том числе 25 - преподавателями кафедры социологии (10 докторских - Д. Л. Агранат, М. В. Вдовина, Е. А. Гришина, В. Л. Доблаев, А.И.Ковалева, И.А. Полуэхтова, Н. А. Селиверстова, И. А. Сурина, С. Н. Щеглова и 16 кандидатских - Д. Л. Агранат, И. В. Воробьева, В. В. Воробьев, В. И. Горбачева, А. Г. Голова, Ч. И. Ильдарханова, О. Я. Калачева, М. Я. Курганская, С. В. Лу- 
ков, О. О. Намлинская, С. В. Овчинникова, Д. Ю. Овсянников, Н. А. Селиверстова, И. А. Сурина, Д. А. Тихомиров, К. И. Фальковская, С. Н. Щеглова) по специальностям 22.00.04 - социальная структура, социальные институты и процессы; 22.00.06 - социология культуры; 22.00.08 - социология управления. Диссертационный совет предъявлял высокие требования к качеству диссертаций. Он неоднократно выполнял поручения Экспертного совета ВАК при Минобрнауки РФ по дополнительному заключению по докторским диссертациям.

На базе обозначенных основных концепций, а также других концептуальных разработок и идей, выдвинутых и обоснованных учеными МосГУ в области социологических наук, проведены исследования с широким применением как количественных, так и качественных методов, сформированы новые образовательные комплексы в таких новых областях социологического знания, как социальная ювенология, гендерология, социология рекламной деятельности, социокультурное проектирование, социальная инноватика и др.

Кафедра социологии университета ведет разработку комплексных проблем молодежи, в которых активное участие принимают преподаватели, аспиранты, студенты вуза. Наиболее значимые результаты достигнуты в разработке проблем социального статуса молодежи, молодой семьи, особенностей социализации молодежи, социальной адаптации молодежи с ограниченными возможностями, чтения молодежи как практик культурного воспроизводства.

Кафедра социологии объединяет свои усилия с Институтом фундаментальных и прикладных исследований и другими подразделениями университета в проведении социологических исследований, направленных на осмысление внутренних процессов в Московском гуманитарном университете. В этой связи эмпирические исследования проводятся на регулярной основе в студенческой среде и среди аспирантов. В режиме мониторинга проводятся с 2004 г. исследования «Первокурсник Московского гуманитарного университета» и «Учебно-воспитательный процесс глазами студентов» (руководители А. И. Ковалева и Вал. А. Луков).

Проблематика научной школы социологии молодежи МосГУ отражена в значительном числе научных проектов, поддержанных российскими научными фондами (РГНФ, РФФИ, Роснаука) и международными организациями (ЮНЕСКО, ЮНИСЕФ и др.). Ряд социологических исследований выполнялся по заказу органов государственной власти, органов местного самоуправления, государственных учреждений, общественных объединений и других сторонних организаций. Для Правительства Москвы кафедрой социологии и ИФПИ были проведены мониторинговые исследования «Детское движение Москвы: состояние и перспективы развития» (2007, 2009 гг.), для ЮНИСЕФ - социологическое исследование «Дети улиц: со- 
стояние и проблемы» (2008-2009 гг.), для Всемирного Русского Народного Собора - экспертиза Доктрины «Молодежь России» (2008 г.) и др.

Ряд эмпирических исследований, проведенных кафедрой социологии, носил прикладной характер. Таковы, в частности, проведенные в 2007 г. два этапа социологического исследования «Чтение классической литературы студентами московских вузов» (руководитель Н. А. Селиверстова), маркетинговое исследование по заказу ОАО «Молодая гвардия» «Учет потребительского поведения москвичей в возрасте 15-40 лет на книжном рынке в деятельности ОАО «Молодая гвардия» (руководитель А.И. Ковалева) и др.

Кафедра принимает участие в исследовательских проектах последних лет, имеющих важное значение для развития научной школы социологии молодежи.

Первый - проект, выполненный в 2014-2015 гг. по Государственному контракту № 09.028.12.0066 от 24.10.2014 г. «Внедрение эффективных моделей организационно-методического обеспечения программ воспитания детей и молодежи, содействующих повышению их социальной активности и временной занятости, основанных на правовой грамотности и навыках самоуправления» (руководитель первого этапа Вал. А. Луков). На основе изучения опыта более 40 регионов были выделены соответствующие модели, в которых выявлена связь с задачами государственной молодежной политики. Успешно выполненный проект показал продуктивность концепций, сформированных в рамках научной школы, их применимость к современным условиям. Среди других результатов работы по проекту в 2015 г. было подготовлено методическое пособие «Повышение социальной активности и временной занятости детей и молодежи на основании навыков самоуправления» для педагогических работников и руководителей общеобразовательных организаций, специалистов и руководителей органов, осуществляющих полномочия по работе с детьми и молодежью под общей редакцией Вал. А. Лукова.

Второй значимый для развития научной школы проект - электронная энциклопедия «Социология молодежи» (проект поддержан грантом РГНФ). Проект осуществляется в 2015-2016 гг. группой сотрудников Московского гуманитарного университета (руководитель Вал. А. Луков, в составе участников проекта от кафедры: А. И. Ковалева, Н. А. Селиверстова, Н. А. Перинская) и опирается на подходы, разработанные научной школой социологии молодежи МосГУ. Теоретико-методологическим основанием данного проекта является тезаурусный подход, получающий в последнее время все более широкое признание в гуманитарных и социальных науках. Таким образом, проект замышлен как фундаментальное исследование молодежи, молодежного движения, молодежной политики 
с применением тезаурусного принципа построения энциклопедического электронного издания. Оно предоставляет широкий доступ к идеям, теоретическим разработкам, эмпирическим данным в сфере социологии молодежи и смежных областях научного знания как исследователей и практиков, занимающихся изучением и воспитанием молодежи, так и самой молодежи, включая молодых исследователей.

Третий значимый для развития научной школы и кафедры проект «Социокультурная динамика и социализация молодежи», который осуществляется в Московском гуманитарном университете с 2011 г. и позволяет преподавателям кафедры реализовать свои научные интересы, связанные с социокультурными изменениями в России (Алиев, 2015; Короткова, 2014; Перинская, 2015: Электр. ресурс; Ромашова, 2015: Электр. ресурс; Селиверстова, 2012, 2015 и др. публикации).

\section{СПИСОК ЛИТЕРАТУРЫ}

Агранат, Д. Л., Васильева, Н. В., Гневашева, В. А., Ковалева, А. И., Луков, В. А., Селиверстова, Н. А. (2005) Трудовая социализация подростков: По материалам социологического исследования. М. : Изд-во Моск. гуманит. ун-та. 63 с.

Алиев, В. В. (2015) Основы исследования социальной субъектности молодежи // Знание. Понимание. Умение. № 1. С. 152- 161.

Васильева, Н. В., Кочнев, С. В. (2012) Участие молодежи в принятии общественно значимых решений. М. : Изд-во Моск. гуманит. ун-та. 147 с.

Государственная молодежная политика: российская и мировая практика реализации в обществе инновационного потенциала новых поколений (2013) : науч. монография / под общ. ред. Вал. А. Лукова. М. : Изд-во Моск. гуманит. ун-та. 718 с.

Жулковска, Т., Ковалева, А. И., Луков, В. А. (2003) «Ненормальные» в обществе: Социализация людей с ограниченными интеллектуальными возможностями. М. ; Щецин : Изд-во Моск. гуманит. ун-та. 432 с.

Ковалева А. И. (1997) Социализационная норма в современном российском обществе : автореф. дис.... д-ра социол. наук. М. 32 с.

Ковалева, А. И., Луков, В. А. (1999) Социология молодежи: Теоретические вопросы. М. : Социум. 351 с.

Ковалева, А. И., Реут, М. Н. (2001) Социализация неслышащей молодежи. М. : Социум. 222 с.

Ковалева, А. И. (2006) Личность молодого человека // Знание. Понимание. Умение. № 2. С. 221-222.

Ковалева ,А. И. (2011) Общество и личность. М. : Изд-во Моск. гуманит. ун-та. 204 с.

Ковалева, А. И. (2012) Методологические проблемы исследования со- 
циализации // Знание. Понимание. Умение. № 2. С. 19-24.

Ковалева, А. И., Богданова, В. В. (2012) Траектория социализации. М. : Изд-во Моск. гуманит. ун-та. 184 с.

Ковалева, А. И., Луков, Вал. А. (2012) Социализация: социальнофилософский, социологический и социально-психологический аспекты понимания // Философия и культура. № 3. С. 27-35.

Короткова, М. С. (2014) Социальный статус студенчества в субъективном измерении: результаты эмпирического исследования // Знание. Понимание. Умение. № 4. С. 108-117.

Луков, Вал. А., Агранат, Д. Л. (2005) Курсанты: Плац. Быт. Секс. Социологическое и социально-психологическое исследование. М. : Изд-во Моск. гуманит. ун-та. 272 с.

Луков, В. А., Луков, Вл. А. (2008) Тезаурусы: Субъектная организация гуманитарного знания. М. : Изд-во Нац. ин-та бизнеса. 784 с.

Луков, Вал. А. (2010) Социальное проектирование. 9-е изд. М. : Изд-во Моск. гуманит. ун-та ; Флинта. 239 с.

Луков, Вал. А. (2011а) Биосоциология // Знание. Понимание. Умение. № 3. С. 319-323.

Луков, Вал. А. (2011b) Органицизм и биосоциология: их связь в свете тезаурусного подхода // Тезаурусный анализ мировой культуры : сб. науч. трудов. Вып. 22 / под общ.ред. Вл. А. Лукова. М. : Изд-во Моск. гуманит. ун-та. С. 22-37.

Луков, В. А., Луков, Вл. А. (2013) Тезаурусы II: Тезаурусный подход к пониманию человека и его мира. М. : Изд-во Нац. ин-та бизнеса. 640 с.

Луков, В. А. (2013) Биосоциология молодежи: теоретикометодологические основания. М. : Изд-во Моск. гуманит. ун-та. 430 с.

Луков, Вал. А., Луков, Вл. А. (2004) Тезаурусный подход в гуманитарных науках // Знание. Понимание. Умение. № 1. С. 93-100.

Луков, В. А., Луков, Вл. А. (2014) Методология тезаурусного подхода: стратегия понимания // Знание. Понимание. Умение. № 1. С. 18-35.

Луков, В. А. (2012) Теории молодежи: Междисциплинарный подход. М. : $\mathrm{Kaнон}^{+} .528$ с.

Луков, Вал. А., Луков, С. В., Погорский, Э. К. (2012) Инновационный потенциал новых поколений и молодежная политика // Молодіжна політика: проблеми та перспективи. Вип. 3. : [зб. наук.праць] / наук. ред. С. Шудло. Дрогобич. С. 10-15.

Луков, В. А., Погорский, Э. К. (2014) Информационное общество и молодежь. М. : Изд-во Моск. гуманит. ун-та. 159 с.

Перинская, Н. А. (2005) Ресоциализация // Знание. Понимание. Умение. № 4. С. 161-162.

Перинская, Н. А. (2015) Студенты и «свободные деньги» [Электрон- 
ный ресурс] // Научные труды Московского гуманитарного университета. № 4. URL: http://journals.mosgu.ru/trudy/article/view/53 (дата обращения: 12.06.2016). DOI: http://dx.doi.org/10.17805/trudy.2015.4.9

Ромашова, Л. О. (2013) Противоречия в профессиональном самоопределении молодежи // Знание. Понимание. Умение. № 3. С. 179- 182.

Ромашова Л.О. (2015) Современное состояние рынка труда молодежи в России [Электронный ресурс] // Научные труды Московского гуманитарного университета. № 4. URL: http://journals.mosgu.ru/trudy/article/ view/48 (дата обращения: 12.06.2016). DOI: http://dx.doi.org/10.17805/ trudy.2015.4.4

Селиверстова, Н. А. (2009) Роман М. Булгакова «Мастер и Маргарита» в прочтении студентов (анализ дневников читателей) // Знание. Понимание. Умение. № 2. С. 194-204.

Селиверстова, Н. А. (2011) Социальные практики чтения контента Интернета в студенческой среде // Знание. Понимание. Умение. № 1. С. 213-217.

Селиверстова, Н. А. (2012) Культурное воспроизводство: вопросы методологии и методики исследования // Знание. Понимание. Умение. № 3. С. 59-63.

Селиверстова, Н. А. (2015) Образовательный опыт как понятие социологии // Знание. Понимание. Умение. № 2. C. 79-87. DOI: http://dx.doi. org/10.17805/zpu.2015.2.8

Селиверстова, Н. А., Юмашева, Н. Д. (2009) Чтение в студенческой среде: опыт социологического исследования. М. : Российская книжная палата. 108 с.

Усманов, Б. Ф. (2012) Молодежь и перспективы политического процесса в России // Знание. Понимание. Умение. № 2. С. 79-83.

Ковалева Антонина Ивановна - доктор социологических наук, профессор, проректор по учебной работе, заведующий кафедрой социологии Московского гуманитарного университета, академик Международной академии наук (IAS). Адрес: 111395, Россия, г. Москва, ул. Юности, д. 5, корп. 1. Тел.: +7 (499) 374-60-21. Эл. адрес: aikovaleva@mail.ru

Луков Валерий Андреевич - доктор философских наук, профессор, директор Института фундаментальных и прикладных исследований Московского гуманитарного университета, заслуженный деятель науки Российской Федерации, вице-президент Международной академии наук (IAS, Инсбрук, Австрия), академик Международной академии наук педагогического образования. Адрес: 111395, Россия, г. Москва, ул. Юности, д. 5, корп. 6. Тел.: +7 (499) 374-75-95. Эл. адрес: v-lukov@list.ru 
Kovaleva Antonina Ivanovna, Doctor of Sociology, Professor and Chair, Department of Sociology; Vice Rector for Academic Affairs, Moscow University for the Humanities; Full Member, International Academy of Sciences (IAS). Postal address: 5 Bldg. 1 Yunosti St., 111395 Moscow, Russian Federation. Tel.: +7 (499) 374-60-21. E-mail: aikovaleva@mail.ru

Lukov Valery Andreevich, Doctor of Philosophy, Professor, Director, Institute of Fundamental and Applied Studies, Moscow University for the Humanities; Honored Scientist of the Russian Federation; Vice President, International Academy of Science (Innsbruck, Austria); Full member, International Teacher's Training Academy of Science. Postal address: 5 Yunosti St., 111395 Moscow, Russian Federation. Tel.: +7 (499) 374-75-95. E-mail: v-lukov@list.ru 